
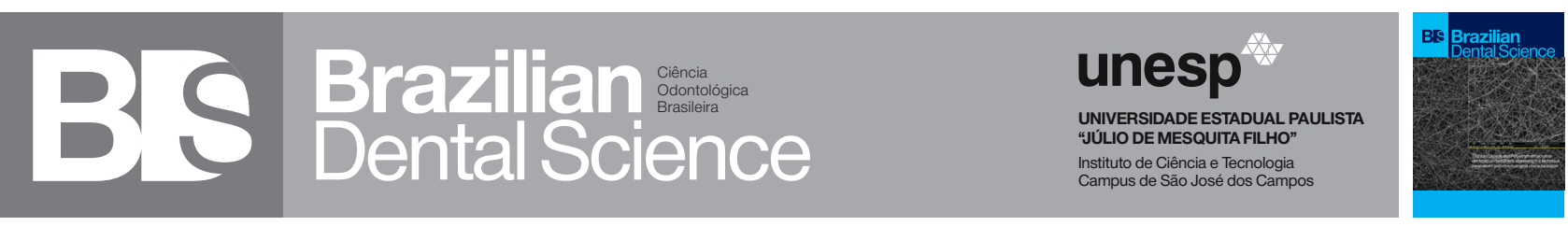

\title{
Restorative strategies for weakened roots: Systematic review and Meta-analysis of in vitro studies
}

\author{
Estratégias restauradoras para raízes fragilizadas: uma revisão sistemática e Meta-análise de estudos in vitro \\ Gislene CORREAA ${ }^{1}$, Lucas Pradebon BRONDANI ${ }^{1}$, Rafael Sarkis ONOFRE ${ }^{2}$, César Dalmolin BERGOLI ${ }^{1}$ \\ 1 - Graduate Program in Dentistry - Federal University of Pelotas - Pelotas - RS - Brazil. \\ 2 - Graduate Program in Dentistry - IMED - Passo Fundo - RS - Brazil.
}

\begin{abstract}
This study evaluated fracture resistance values and failure mode of weakened roots restored with cast post and core, fiber post and anatomical posts. In vitro studies, published in English, Portuguese and Spanish, that evaluated weakened roots restored with at least two of mentioned strategies were searched for in three databases MEDLINE, PubMed and Scopus until June 2017; there was no restriction regarding the publication year. Fracture resistance values were obtained, and the following comparisons: cast post and core vs. fiber post and vs. anatomical post and fiber post vs. anatomical post were performed. Meta-analyses were conducted using the random effects model to calculate the combined effect of the difference between the averages. Six articles were included in the study. There was no significant difference between the fracture resistance values, but more catastrophic failures were observed on cast post and core, and the included studies presented a low risk of bias for the most domains. It was concluded that weakened roots restored with the searched strategies seem to have similar fracture strength, but fiber and anatomic post decreases the possibility of catastrophic failure.
\end{abstract}

\section{KEYWORDS}

Review; Root; Dental restoration.

\section{RESUMO}

Este estudo avaliou os valores de resistência à fratura e modo de falha de raízes fragilizadas restauradas com núcleos metálicos fundidos, pinos de fibra de vidro e pinos anatômicos. Foram pesquisados estudos in vitro, publicados em inglês, português e espanhol, que avaliaram raízes fragilizadas restauradas com pelo menos duas das estratégias citadas, em três diferentes bases de dados MEDLINE, PubMed e Scopus até junho de 2017; não houve restrição quanto ao ano de publicação. Os valores de resistência à fratura foram obtidos, e as seguintes comparações foram feitas: núcleo metálico fundido vs. pino de fibra de vidro e vs. pino anatômico e pino de fibra de vidro vs. pino anatômico. Meta-análises foram realizadas utilizando o modelo de efeitos randômicos para calcular o efeito combinado da diferença entre as médias. Seis artigos foram incluídos no estudo. Não houve diferença significativa entre os valores de resistência à fratura, mas foram observadas mais falhas catastróficas nos núcleos metálicos fundidos, e os estudos incluídos apresentaram um baixo risco de viés para a maioria dos domínios. Pode-se concluir que raízes fragilizadas, restauradas com as estratégias pesquisadas, parecem ter semelhante resistência à fratura, porém os pinos anatômicos e de fibra de vidro diminuem as possibilidades de falha catastrófica.

\section{PALAVRAS-CHAVE}

Revisão; Raiz; Restauração dentária 


\section{INTRODUCTION}

$\mathrm{T}$ he loss of tooth structure caused by caries, $\perp$ trauma or endodontic retreatments leads to the gradual weakening of the roots. When teeth reach this condition, it is primordial the use of intracanal posts to retain the coronary restoration $[1,2]$.

Among the restorative strategies, cast post and core $(\mathrm{CPC})$ is widely used $[3,4]$, although its technique requires more clinical steps and increases the risk of catastrophic fractures of the remaining tooth [4-7]. The advent of the fiber posts (FP) reduced clinical steps and reduces the chances of catastrophic failures of the root, once its mechanical properties are similar to dentine [2,6-10]. However, the use of fiber posts to restore weakened roots creates a thick cement layer between root dentine and the post, which reduces the bond strength of the set $[11,12]$. Anatomic post (AP) technique was developed to solve this problem with the application of composite resin around the fiber post and consequently precise adaptation between the post and the canal walls $[13,14]$.

An important characteristic of a restorative strategy is to present high values of fracture resistance and allow possible repairs in case of which restorative strategy would be more appropriated for the restoration of weakened teeth considering these characteristics $[7,10,13]$. Nevertheless, there is no consensus in the literature about which technique present better behavior to restore weakened roots, also there are no clinical trials regarding this subject.

Thus, this systematic review aimed to compare the load to fracture values of weakened roots restored with cast post and core, glass fiber posts and anatomic posts, as well as the fracture patterns generated among strategies.

This study focused on answering the following patient, problem, or population; intervention; comparison, control, or comparator; outcome (PICO) question: Witch Intra-radicular (cast post and core, fiber post and anatomical posts) retainer presents the best biomechanical behavior on weakened roots submitted to the load-to-fracture in vitro test?

The null hypothesis tested was that there would be no difference between the restorative structure fracture. Some studies had evaluated

strategies regarding the load to fracture values.

\section{MATERIAL AND METHODS}

The basic structure of this review was conducted based on the Cochrane Handbook for Systematic Reviews of Interventions [15] and followed the four steps from the flow chart of "Preferred Reporting Items for Systematic Reviews and Meta-analysis (PRISMA) Statement" [16].

\section{Search Strategy and Eligibility Criteria}

Searches were performed within electronic databases (MEDLINE/Pubmed and Scopus), and the last search was carried out in 2017 June. The search strategy used is described in Table I. The strategy was created based on Medline/Pubmed database and adapted to Scopus. Literature search results were de-duplicated using EndNote X7 software (Thomson Reuters, New York, NY, USA). After an initial search in electronic databases, a hand search was made on the references of the selected articles, to verify the presence of any other possible source of information.

Table I - Description of the search terms used on the survey

\begin{tabular}{|c|c|}
\hline Terms & Description \\
\hline Retainers & 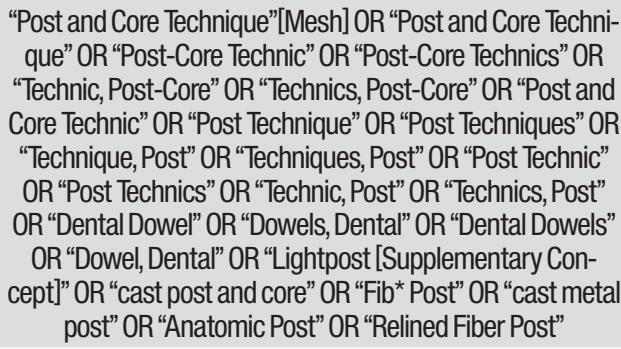 \\
\hline $\begin{array}{l}\text { Weake- } \\
\text { ning }\end{array}$ & 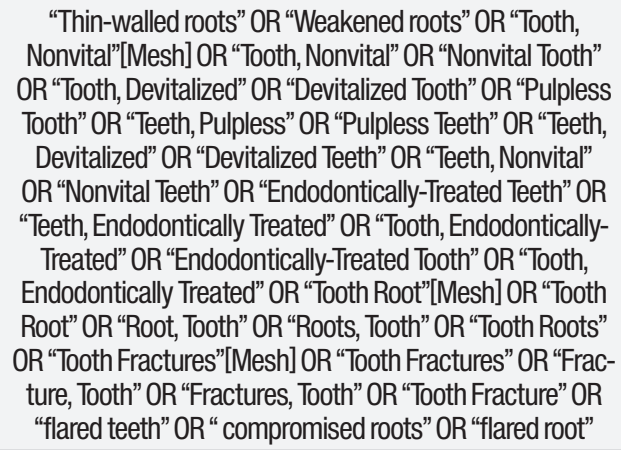 \\
\hline $\begin{array}{l}\text { Load to } \\
\text { fracture }\end{array}$ & $\begin{array}{l}\text { "failure" OR "fracture strength" OR “load to fracture" OR } \\
\text { "fracture load" OR "Fracture resistance" }\end{array}$ \\
\hline
\end{tabular}


The inclusion criteria were: (1) articles published in English (2) in vitro studies that compared fracture resistance of weakened roots with at least two of the following restorative strategies: cast post and core, glass fiber post and anatomic post; (3) use of single-root bovine or human teeth; (4) roots with a maximum of $1 \mathrm{~mm}$ of dentin remaining thickness; (5) the post space preparation should be $2 / 3$ of the remaining radicular length; (6) specimens should be restored with single crown (metallic or metal-ceramic); (7) load to fracture test should be conducted with an angulation of $45^{\circ}$ with the long axis of the teeth and (8) highest speed of $\mathrm{mm} / \mathrm{min}$.

\section{Study Selection}

The literature search was made by two independent reviewers. Initially, the reviewers evaluated the article titles, and if the titles had inclusion potential their abstracts were assessed. After a detailed evaluation of the abstracts, the articles considered eligible were identified and a complete assessment was performed by both reviewers, to define its inclusion or not. In case of discordance between the reviewers about the article inclusion, a third reviewer was consulted.

\section{Data collection}

The following parameters were extracted simultaneously by both reviewers, using a standard outline: Author(s) and year of publication, journal, alloy used to produce the cast post and core, coronary diameter of the post, type of fiber, post design, load to fracture values and standard deviation, type of fracture, specimen length, depth of weakening, remaining thickness, type of cement and material of cast metal post and core, aging of the specimens and presence of ferrule. Also, the number and the mode of the failures for each strategy were collected and classified in two groups: Favorable (any fracture that was possible to repair, as core fracture, root fracture above the periodontal ligament, adhesive failure of the post, adhesive failure of the crown); Unfavorable (root fractures bellow the periodontal ligament).

\section{Risk of bias}

The risk of bias of included studies was assessed based on previous studies $[4,17,18]$. The risk of bias assessed the selected articles according to the report of the following items: the presence of sample size calculation, teeth randomization, previously training operators, followed manufacturer's recommendation and blinding of test operator. If the author had reported the parameter, this domain was considered as "Low risk", if it was not reported or if it was unclear for the reviewers on the article, the domain was considered as "Unclear", and if the authors reported that the parameter was not followed or controlled the domain was classified as "High risk". One researcher made the analysis and reviewed by another using the Review Manager 5.3 Software (Copenhagen: The Nordic Cochrane Centre, The Cochrane Collaboration, 2014).

\section{Statistical Analysis}

The studies characteristics were descriptively summarized. The outcome considered was the load to fracture in Newton. The meta-analyses were conducted using random effect models to calculate the pooled mean differences between glass fiber post vs. cast post and core, glass fiber post vs. anatomic post and cast post and core vs. anatomic post since these models provide. All summary estimates were reported with point estimates and corresponding 95\% confidence intervals (CIs). Heterogeneity was assessed using the Cochrane Q statistics and the I2 test ( $>75 \%$ indicating high heterogeneity). The analyses were conducted using Review Manager 5.3 Software. Considering the analysis between glass fiber post and cast metal post and core, two separate analyses were performed, once Balkaya et al. 2013 [19] presented two different groups of glass fiber post with different diameters $(\phi=1.3 \mathrm{~mm}$ e $\phi 1.7 \mathrm{~mm})$ and one group restored with CPC.

\section{RESULTS}

\section{Descriptive analysis}

The flowchart of the systematic review is shown in Figure 1. A total of 6 articles [7,10,19$22]$ were included in the analysis. Four articles $[7,10,20,21]$ evaluated CPC, FP, and AP while one [19] presented only CPC and FP groups and one compared FP and AP [22].

\section{Studies Characteristics}

The characteristics of included studies are presented in Table II. 


\section{PRISMA 2009 Flow Diagram}

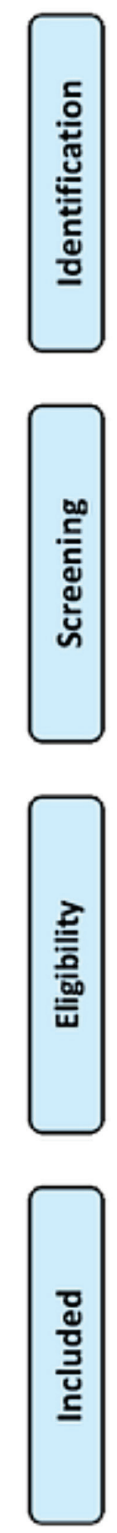

\section{Records identified through database searching} $(n=2809)$
Additional records identified through other sources $(n=0)$

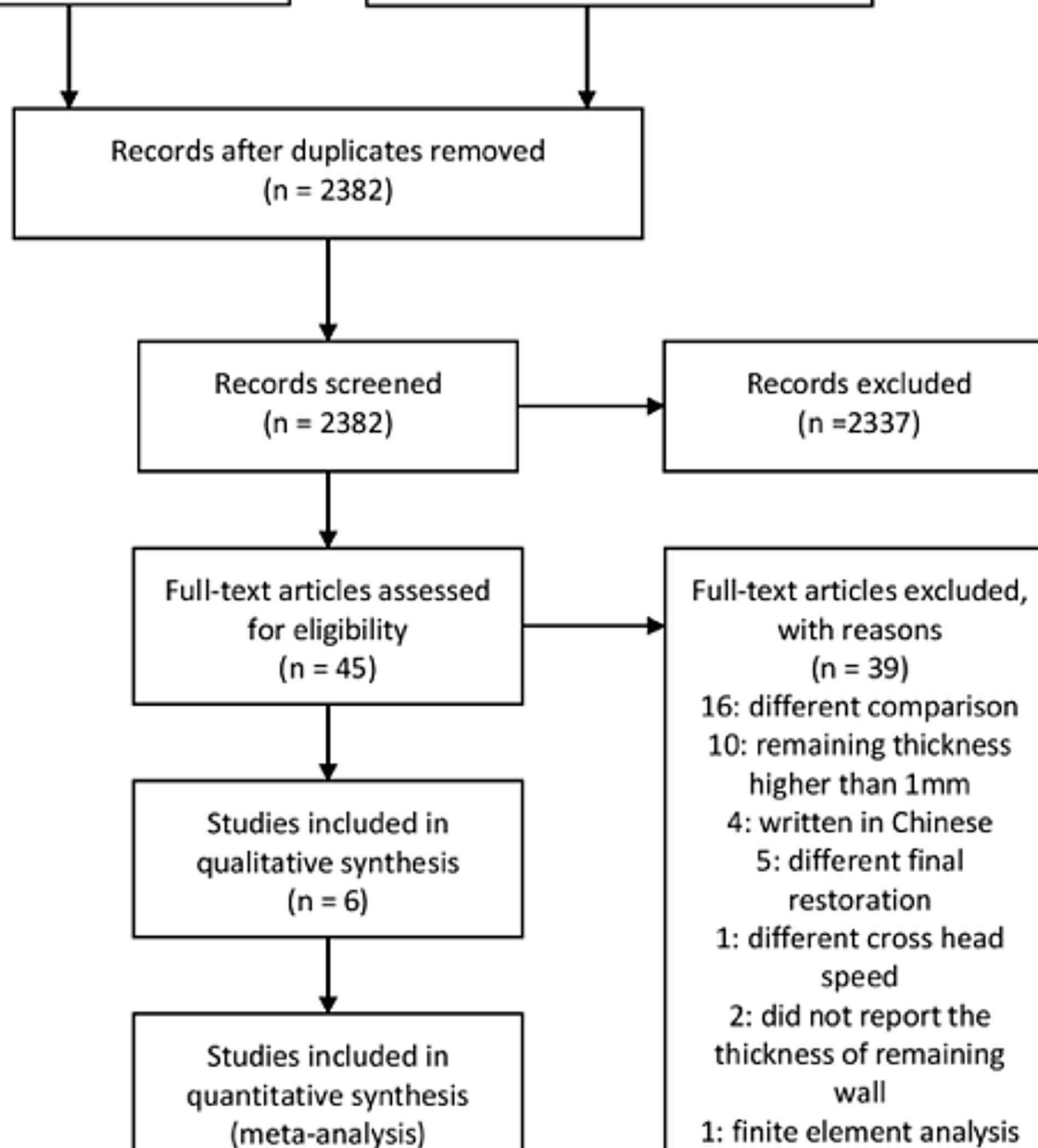

$$
(n=6)
$$

1: finite element analysis

From: Moher D, Liberati A, Tetzlaff J, Altman DG, The PRISMA Group (2009). Preferred Reporting Items for Systematic Reviews and MetaAnalyses: The PRISMA Statement. PLoS Med 6(6): e1000097. doi:10.1371/journal.pmedi 000097

\section{For more information, visit www, prisma-statement,ors.}


Table II - Characteristics of each included study

\begin{tabular}{|c|c|c|c|c|c|c|c|c|c|c|c|c|c|}
\hline & Type of Post & $\begin{array}{l}\text { Mate- } \\
\text { rial }\end{array}$ & $\begin{array}{l}\text { Coronal } \\
\text { Diameter }\end{array}$ & Post Design & $\begin{array}{l}\text { Frac- } \\
\text { ture } \\
\text { Load }\end{array}$ & SD & $\begin{array}{c}\text { Cemen- } \\
\text { tation } \\
\text { Material }\end{array}$ & $\begin{array}{l}\text { Deep } \\
\text { of fra- } \\
\text { gilized }\end{array}$ & $\begin{array}{l}\text { Thick- } \\
\text { ness } \\
\text { of } \\
\text { re- } \\
\text { main- } \\
\text { ing }\end{array}$ & $\begin{array}{l}\text { Speci- } \\
\text { men } \\
\text { Length }\end{array}$ & Aging & $\begin{array}{c}\text { Fer- } \\
\text { rule } \\
\text { effect }\end{array}$ & $\begin{array}{l}\text { Relined } \\
\text { material }\end{array}$ \\
\hline \multirow{3}{*}{$\begin{array}{c}\text { Balkaya } \\
\text { andBirdal, } \\
2013\end{array}$} & Fiber post & $\begin{array}{l}\text { Glass } \\
\text { fiber }\end{array}$ & $1.3 \mathrm{~mm}$ & Tapered end & 331.6 & 135.2 & $\begin{array}{l}\text { Resin } \\
\text { cement }\end{array}$ & \multirow{3}{*}{$7 \mathrm{~mm}$} & \multirow{3}{*}{$1 \mathrm{~mm}$} & \multirow{3}{*}{13} & \multirow{3}{*}{ No } & \multirow{3}{*}{ Yes } & \multirow{3}{*}{ NA } \\
\hline & 40 & 49.38 & $\begin{array}{l}\text { Unspecified } \\
\text { diabetes } \\
\text { mellitus }\end{array}$ & 32 & & & & & & & & & \\
\hline & 36 & 44.44 & $\begin{array}{l}\text { Parkinson } \\
\text { disease }\end{array}$ & 12 & & & & & & & & & \\
\hline \multirow{3}{*}{$\begin{array}{l}\text { Gastro-oe- } \\
\text { sophageal } \\
\text { refluxadi- } \\
\text { sease }\end{array}$} & Fiber post & $\begin{array}{l}\text { Glass } \\
\text { fiber }\end{array}$ & $1.1 \mathrm{~mm}$ & $\begin{array}{l}\text { Parallel with } \\
\text { retentions }\end{array}$ & 380.97 & 75.84 & $\begin{array}{l}\text { Resin } \\
\text { cement }\end{array}$ & \multirow{3}{*}{$7 \mathrm{~mm}$} & \multirow{3}{*}{$1 \mathrm{~mm}$} & \multirow{3}{*}{15} & \multirow{3}{*}{ Yes } & \multirow{3}{*}{ Yes } & \multirow{3}{*}{$\begin{array}{c}\text { Compo- } \\
\text { site resin } \\
\text { (Z250- } \\
\text { 3M ESPE) }\end{array}$} \\
\hline & $\begin{array}{l}\text { Cast post and } \\
\text { core }\end{array}$ & $\mathrm{Ni}-\mathrm{Cr}$ & Not reported & Not reported & 262.44 & 95.17 & $\begin{array}{l}\text { Resin } \\
\text { cement }\end{array}$ & & & & & & \\
\hline & Anatomic post & $\begin{array}{l}\text { Glass } \\
\text { fiber }\end{array}$ & $1.1 \mathrm{~mm}$ & $\begin{array}{l}\text { Parallel with } \\
\text { retentions }\end{array}$ & 380.97 & 75.84 & $\begin{array}{l}\text { Resin } \\
\text { cement }\end{array}$ & & & & & & \\
\hline \multirow{6}{*}{$\begin{array}{l}\text { Broch etal, } \\
2015\end{array}$} & Fiber post & $\begin{array}{l}\text { Glass } \\
\text { fiber }\end{array}$ & $1.8 \mathrm{~mm}$ & Tapered end & 976.7 & 236.28 & $\begin{array}{l}\text { Resin } \\
\text { cement }\end{array}$ & \multirow{6}{*}{$5 \mathrm{~mm}$} & \multirow{6}{*}{$1 \mathrm{~mm}$} & \multirow{6}{*}{15} & No & \multirow{6}{*}{ No } & \multirow{6}{*}{$\begin{array}{c}\text { Flow } \\
\text { compo- } \\
\text { site resin } \\
\text { (Oppalis } \\
\text { - FGM) }\end{array}$} \\
\hline & Fiber post & $\begin{array}{l}\text { Glass } \\
\text { fiber }\end{array}$ & $1.8 \mathrm{~mm}$ & Tapered end & 1017.4 & 230.70 & $\begin{array}{l}\text { Resin } \\
\text { cement }\end{array}$ & & & & Yes & & \\
\hline & $\begin{array}{l}\text { Cast post and } \\
\text { core }\end{array}$ & $\mathrm{Ni}-\mathrm{Cr}$ & No report & No report & 1396.8 & 265.95 & $\begin{array}{l}\text { Resin } \\
\text { cement }\end{array}$ & & & & No & & \\
\hline & $\begin{array}{l}\text { Cast post and } \\
\text { core }\end{array}$ & $\mathrm{Ni}-\mathrm{Cr}$ & No report & No report & 1120.0 & 242.26 & $\begin{array}{l}\text { Resin ce- } \\
\text { ment }\end{array}$ & & & & Yes & & \\
\hline & Anatomic post & $\begin{array}{l}\text { Glass } \\
\text { fiber }\end{array}$ & $1.8 \mathrm{~mm}$ & Tapered end & 1103.5 & 192.1 & $\begin{array}{l}\text { Resin } \\
\text { cement }\end{array}$ & & & & No & & \\
\hline & Anatomic post & $\begin{array}{l}\text { Glass } \\
\text { fiber }\end{array}$ & $1.8 \mathrm{~mm}$ & Tapered end & 780 & 200.8 & $\begin{array}{l}\text { Resin } \\
\text { cement }\end{array}$ & & & & Yes & & \\
\hline \multirow{3}{*}{$\begin{array}{l}\text { Silva et al, } \\
2011\end{array}$} & Fiber post & $\begin{array}{l}\text { Glass } \\
\text { fiber }\end{array}$ & $1.5 \mathrm{~mm}$ & $\begin{array}{c}\text { Tapered end } \\
\text { with reten- } \\
\text { tions }\end{array}$ & 620.2 & 164.2 & $\begin{array}{l}\text { Resin } \\
\text { cement }\end{array}$ & \multirow{3}{*}{$9 \mathrm{~mm}$} & \multirow{3}{*}{$1 \mathrm{~m}$} & \multirow{3}{*}{$15 \mathrm{~mm}$} & \multirow{3}{*}{ Yes } & \multirow{3}{*}{ Yes } & \multirow{3}{*}{$\begin{array}{l}\text { Compo- } \\
\text { site resin } \\
\text { (Z250- } \\
\text { 3MESPE) }\end{array}$} \\
\hline & $\begin{array}{l}\text { Cast post and } \\
\text { core }\end{array}$ & $\mathrm{Ni}-\mathrm{Cr}$ & Not reported & Not reported & 625.3 & 164.3 & $\begin{array}{l}\text { Resin } \\
\text { Cement }\end{array}$ & & & & & & \\
\hline & Anatomic post & $\begin{array}{l}\text { Glass } \\
\text { fiber }\end{array}$ & $1.5 \mathrm{~mm}$ & $\begin{array}{l}\text { Tapered end } \\
\text { with reten- } \\
\text { tions }\end{array}$ & 949.8 & 210.6 & $\begin{array}{l}\text { Resin } \\
\text { Cement }\end{array}$ & & & & & & \\
\hline \multirow{3}{*}{$\begin{array}{l}\text { Wandscher } \\
\text { etal, } 2014\end{array}$} & Fiber post & $\begin{array}{l}\text { Glass } \\
\text { fiber }\end{array}$ & $1.8 \mathrm{~mm}$ & Double taper & 282.2 & 64.7 & $\begin{array}{l}\text { Resin } \\
\text { cement }\end{array}$ & \multirow{3}{*}{$6 \mathrm{~mm}$} & \multirow{3}{*}{$0.5 \mathrm{~mm}$} & \multirow{3}{*}{$16 \mathrm{~mm}$} & \multirow{3}{*}{ yes } & & Compo- \\
\hline & $\begin{array}{l}\text { Cast post and } \\
\text { core }\end{array}$ & $\mathrm{Ni}-\mathrm{Cr}$ & Not reported & Not reported & 642.6 & 219.5 & $\begin{array}{l}\text { Resin } \\
\text { cement }\end{array}$ & & & & & No & $\begin{array}{l}\text { site resin } \\
\text { (Oppalis }\end{array}$ \\
\hline & Anatomic post & $\begin{array}{l}\text { Glass } \\
\text { fiber }\end{array}$ & $1.8 \mathrm{~mm}$ & Double taper & 216.6 & 63.6 & $\begin{array}{l}\text { Resin } \\
\text { cement }\end{array}$ & & & & & & -FGM) \\
\hline Ferro et al., & Fiber post & $\begin{array}{l}\text { Glass } \\
\text { fiber }\end{array}$ & $1.5 \mathrm{~mm}$ & Parallel & 262.6 & 132.6 & $\begin{array}{l}\text { Resin } \\
\text { cement }\end{array}$ & $10 \mathrm{~mm}$ & $1 \mathrm{~mm}$ & $15 \mathrm{~mm}$ & Yos & Nh & $\begin{array}{l}\text { Compo- } \\
\text { site resin }\end{array}$ \\
\hline 2016 & Anatomic post & $\begin{array}{l}\text { Glass } \\
\text { fiber }\end{array}$ & $1.5 \mathrm{~mm}$ & Parallel & 230.5 & 79.5 & $\begin{array}{l}\text { Resin } \\
\text { cement }\end{array}$ & IUImIII & "IIIII & I5IIIII & res & No & $\begin{array}{c}\text { (Z250- } \\
\text { 3MESPE) }\end{array}$ \\
\hline
\end{tabular}




\section{Type of post}

Studies evaluating CPC used $\mathrm{Ni}-\mathrm{Cr}$ alloy for post and core production. One study reported [19] that the CPC had a $4 \mathrm{~mm}$ diameter and a parallel format, the others did not report format and dimension. All studies evaluating fiber posts used glass fiber as post material, and on the majority of the studies the fiber post had a conical format, and the diameters ranged between $1.1 \mathrm{~mm}$ and $1.8 \mathrm{~mm}$.

\section{Cementation material used}

All studies used resin cement for post cementation. Four $[7,10,21,22]$ studies used dual-cured resin cement. One [19] study used dual-polymerized self-adhesive cement and the other study [20] used self-curing resin cement.

\section{Wakening length and thickness}

Two studies weakened the specimens until a $7 \mathrm{~mm}$ depth $[19,21]$, one article weakened until $9 \mathrm{~mm}$ [20], one until 5mm [7], one article weakened until $6 \mathrm{~mm}$ [10] and one until $10 \mathrm{~mm}$ [22]. Regarding the thickness of weakening, five studies [7,19-22] used $1 \mathrm{~mm}$ of thickness and one study [10] used $0.5 \mathrm{~mm}$.

\section{Specimens aging}

Only one study did not perform the specimens aging [19], four studies made the aging of all specimens [10,20-22], and one study compared the effect with and without aging [7].

\section{Ferrule effect}

Only three studies presented ferrule on the specimens $[7,10,19]$

\section{Relining material}

Among the studies with anatomic post groups, four of them used micro-hybrid composite resin to reline the post [10,20-22], while one article used flow composite resin [7].

\section{Failure mode}

Specimens restored with glass fiber post and anatomic post presented a higher percentage of favorable failures, while the specimens restored with cast post and core presented a higher percentage of unfavorable failures (Table III).

Table III - Failure mode and distribution for each retainer.

\begin{tabular}{|c|c|c|c|}
\hline Retainer & $\begin{array}{c}\text { All assessed } \\
\text { groups relative } \\
\text { sample }\end{array}$ & $\begin{array}{c}\text { Unfavorable } \\
\text { failures }\end{array}$ & $\begin{array}{c}\text { Favorable } \\
\text { failures }\end{array}$ \\
\hline $\begin{array}{c}\text { Glass fiber } \\
\text { post }\end{array}$ & 82 & $37(45.1 \%)$ & $45(54.9 \%)$ \\
\hline $\begin{array}{c}\text { Cast post and } \\
\text { core }\end{array}$ & 65 & $57(88 \%)$ & $8(12 \%)$ \\
\hline $\begin{array}{c}\text { Anatomic } \\
\text { post }\end{array}$ & 63 & $21(33.4 \%)$ & $42(66.6 \%)$ \\
\hline TOTAL & 210 & $115(54.8 \%)$ & $95(45.2 \%)$ \\
\hline
\end{tabular}

Meta-Analysis

Both analyses comparing glass fiber post versus cast post and core did not present statistical differences (1.3: -199.24 IC: $-412.82 / 16.34$ I2 $=93 \% ; \quad 1.7: \quad-163.25 \quad$ IC: $\quad-351.56 / 25.05$ $\mathrm{I} 2=91 \%$ ). Considering the comparison between cast post and core and the anatomic post (117.38 IC: $-166.24 / 401.00 \mathrm{I} 2=95 \%$ ) and the glass fiber post vs. anatomic post (-20.10 IC: $-132.98 / 92.79 \mathrm{I} 2=86 \%$ ) both analyses also did not present statistical differences (figure 2).

\section{Risk of bias}

From the five evaluated domains on the articles, the majority was defined as "Low risk", followed by the "unclear" definition with 2 criteria. None of the domains evaluated was classified as "High risk" on this study (Figure 3). 
A

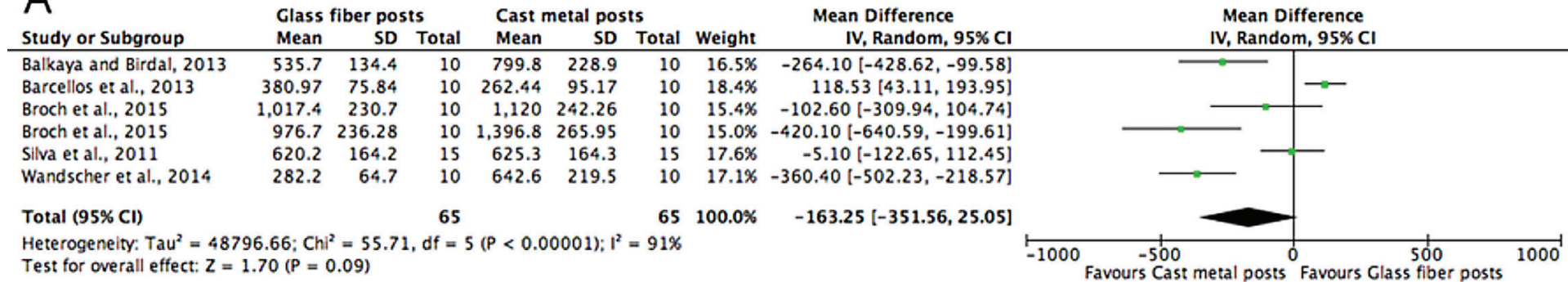

B

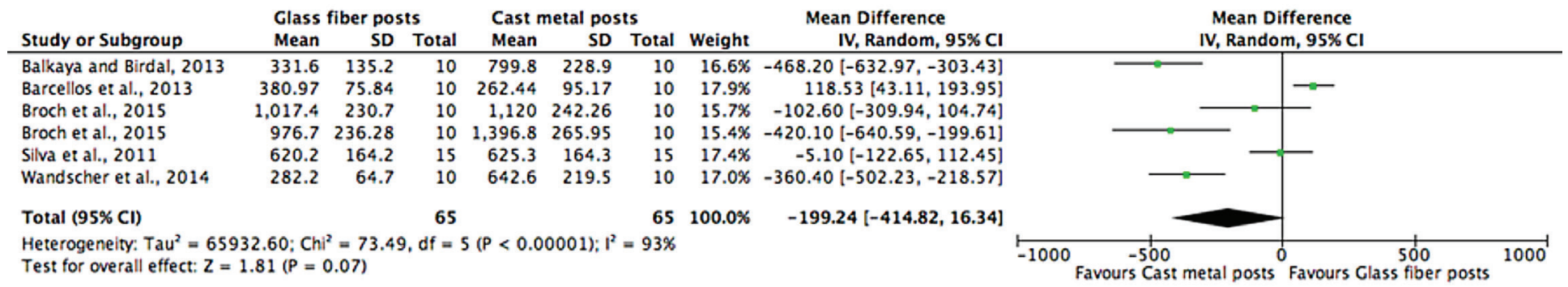

C

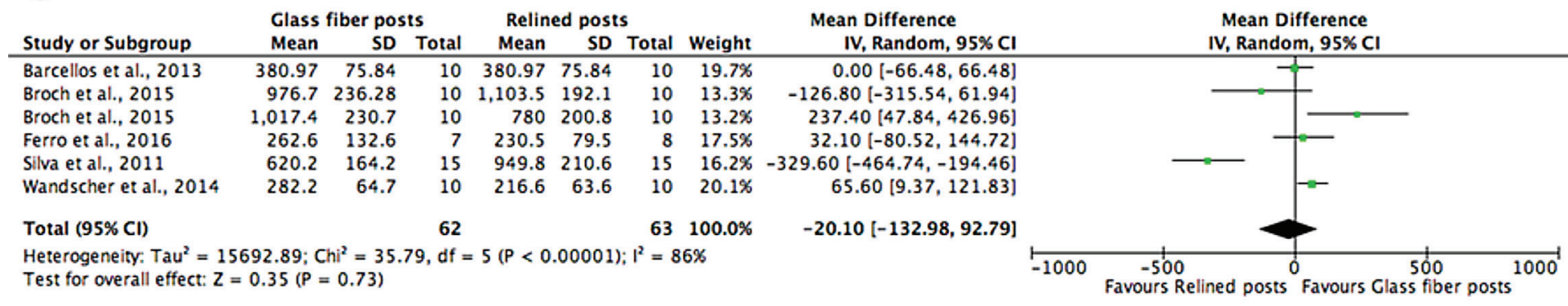

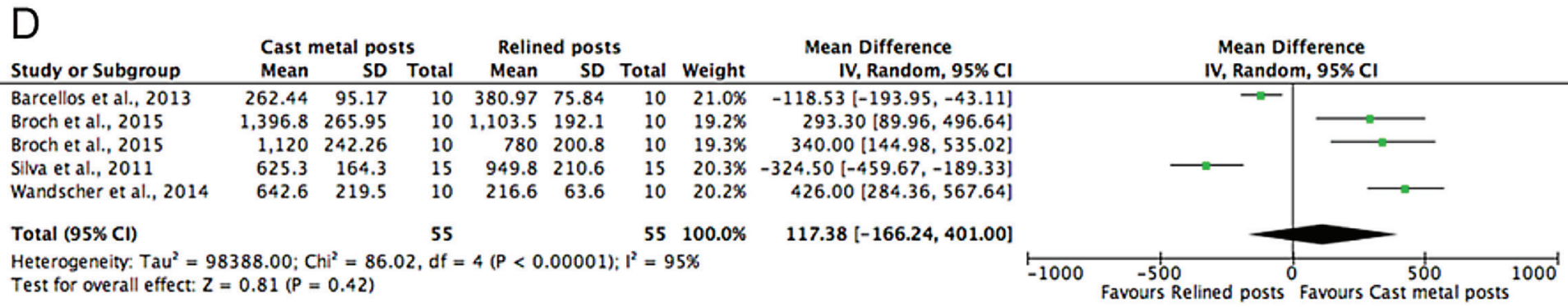

Figure 2 - Forest Plots comparing load to fracture values between: (A) fiber post system (FP with 1.7mm) and CPC; (B) fiber post system (FP with $1.3 \mathrm{~mm}$ ) and $\mathrm{CPC}$; (C) anatomic posts and FP; (D) anatomic post and CPC. 

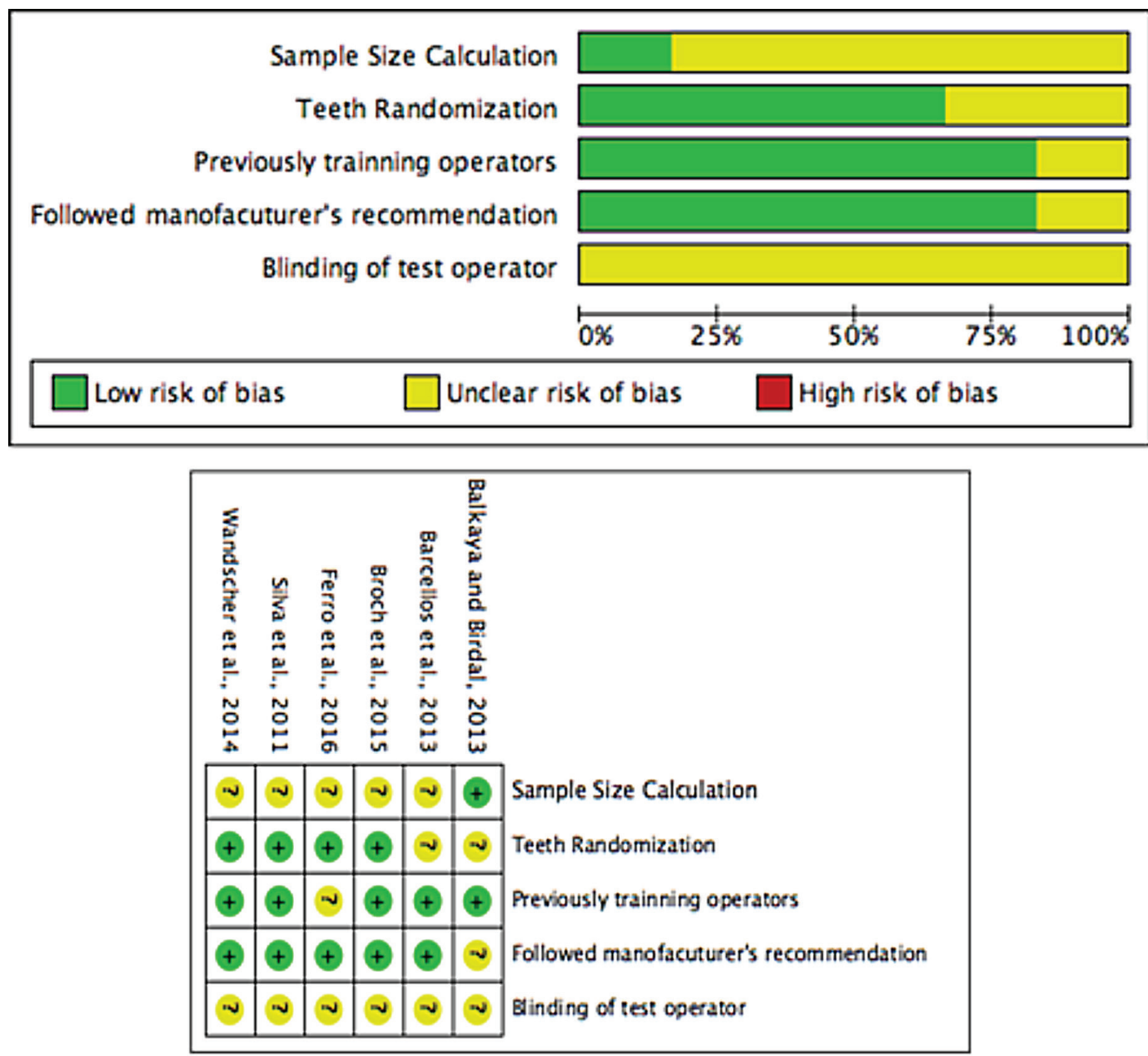

Figure 3 - Risk of bias for each study.

\section{DISCUSSION}

The preservation of remaining coronal walls is a key factor for the success of the restoration of endodontically treated teeth [23]. Thus, the absence of coronal walls, called weakened teeth, is the worst-case scenario for restoration. Several studies were performed trying to find the best restorative option for this scenario. However, there is no consensus on the literature. This review was carried out in order to obtain results to assist in the selection of the technique that presents the higher resistance values and the more favorable failures modes.

This review is the first to suggest that the fracture resistance of weakened roots restored with CPC, FP or AP are similar, accepting the null hypothesis. The main reason for this result is because the use of crowns as final restoration has an important role in the absorption of the forces during the tests. Without the use of crowns, the 
core becomes more suitable to failure, and the load is transmitted directly to post/core complex [24].

Another important fact should be highlighted. The anatomic posts presented values of fracture resistance comparable to the other posts demonstrating that the fit of the post with the root walls and the lower cement thickness obtained have an important role on the biomechanical behavior of the set $[11,12]$.

Studies showed that in specimens restored with FP the composite resin core is the first structure to fail [25]. This structure presents lower resistance than the root, so, sound roots restored with FP presents lower fracture resistance than sound root restored with CPC. In weakened specimens the mechanical behavior is different, as the root is fragilized, teeth restored with CPC tend to fracture with lower forces, presenting similar values than teeth restored with glass fiber posts.

Analyzing the failure modes, it is possible to observe a higher number of unfavorable fractures for the groups restored with cast post and core. This is related with metal mechanical properties, particularly, its elastic modulus (200GPa), which is much higher than the dentin (18GPa). This high elastic modulus is responsible for less bending of the post under mechanical load, resulting in high resistance of the post and therefore a higher load until fracture. Metal concentrates the tension, mainly on the apical third of the root, and this force concentration is transmitted to the canal walls which can result in catastrophic failures of the remaining structure $[26,27]$ and this phenomenon can explain the unfavorable fracture mode when CPC is used.

On the other hand, the use of fiber posts and anatomic post presented higher favorable failures in comparison with the use of CPC (Table III). The highest percentage of favorable failures using fiber post is in accordance with the literature, and because fiber posts present an elastic modulus (30 to $50 \mathrm{GPa}$ ) similar to dentine [28,29] and thus a more uniform stress distribution. Also, there is a tendency that in this scenario the post or composite resin core fail before the root, avoiding unfavorable fractures [23]. The best favorable fractures percentage presented by the anatomic post in relation to the fiber post may be related to the hypothesis that this type of posts tends to bend less than the isolated post, due to the better fit with the root walls, causing less strain on the radicular portion [25].

The small number of studies that met the inclusion criteria in this review and the use of two databases represents a limitation of this study because a greater number of studies could allow some analysis to identify the variables with direct relation on the results. Furthermore, the statistical analyses showed high heterogeneity among the studies. Thus the random effects models were used since they are the most accepted mainly due to the high heterogeneity of the included studies. Factors and variables contributing to this high heterogeneity are hard to identify because a large number of variables involved, this heterogeneity and great number of variables may have affected the results obtained. Maybe with a greater number of studies and with more careful data reporting, this high heterogeneity would be attenuated. Regarding the risk of bias, despite no assessed domain has been classified as "High risk", a great number of the judgments was "Unclear", showing problems on the methodological aspects or poor reporting, also the publication bias should be considered as a limitation factor for this study. Lastly, although the review demonstrates similar behavior among restorative strategies, this result should be interpreted with caution because longterm longitudinal studies in the topic are scarce especially considering the use of anatomic posts.

Notwithstanding the limitations of this systematic review, the results showed a similar behavior of the different strategies used to restore weakened roots, it also showed that the fragilized teeth issue is poorly explored on the literature and more studies, mainly clinical trials, are needed to better explain the mechanical behavior of this kind of restorations. Also the authors need a better reporting protocol, in order to reduce heterogeneity among studies.

So, it can be concluded that the load to fracture values in weakened roots was not affected 
by the restorative strategy (CPC, FP, AP), and that weakened roots restored with glass fiber posts or anatomic posts showed higher probability to present favorable fracture, when compared to those restored with cast post and core.

\section{ACKNOWLEDGES}

This study was financed in part by the Coordenação de Aperfeiçoamento de Pessoal de Nível Superior - Brasil (CAPES) Finance Code 001

\section{REFERENCES}

1. Baba NZ, Goodacre CJ, Daher T. Restoration of endodontically treated teeth: The seven keys to success. Gen Dent. 2009 NovDec;57(6):596-603; quiz 604-5, 595, 679.

2. Ferrari M, Vichi A, Fadda GM, Cagidiaco MC, Tay, FR, Breschi L, et al. A Randomized Controlled Trial of Endodontically Treated and Restored Premolars. J Dent Res. 2012 Jul;91(7 Suppl):72S-78S.

3. Gómez-Polo M, Llidó B, Rivero A, Del Río J, Celemín A. A 10-year retrospective study of the survival rate of teeth restored with metal prefabricated posts versus cast metal posts and cores. J Dent. 2010 Nov;38(11):916-20. doi: 10.1016/j.jdent.2010.08.006. Epub 2010 Aug 14.

4. Sarkis-onofre R, Jacinto R de C, Boscato N, Cenci MS, Pereira-Cenci T. Cast metal vs. glass fibre posts: A randomized controlled trial with up to 3 years of follow up. J Dent. 2014 May;42(5):582-7. doi: 10.1016/j. jdent.2014.02.003. Epub 2014 Feb 12.

5. Ferrari M, Vichi A, Mannocci F, Mason PN. Retrospective study of the clinical performance of fiber posts. Am J Dent. 2000 May;13(Spec No):9B-13B.

6. Veríssimo C, Simamoto JPC, Soares CJ, Noritomi PY, Santos-Filho PC. Effect of the crown, post, and remaining coronal dentin on the biomechanical behavior of endodontically treated maxillary central incisors. J Prosthet Dent. 2014 Mar;111(3):234-46. doi: 10.1016/j. prosdent.2013.07.006. Epub 2013 Nov 5.

7. Broch J, Marchionatti AM, Bergoli CD, Valandro LF, Kaizer OB. Fracture resistance of weakened roots restored with different intracanal retainers. Gen Dent. 2015 May-Jun;63(3):58-63.

8. Al-Omiri MK, Mahmoud AA, Rayyan MR, Abu-Hammad O. Fracture Resistance of Teeth Restored with Post-retained Restorations: An Overview. J Endod. 2010 Sep;36(9):1439-49. doi: 10.1016/j. joen.2010.06.005

9. Juloski J, Fadda GM, Monticelli F, Fajó-Pascual M, Goracci C, Ferrari M. Four-year Survival of Endodontically Treated Premolars Restored with Fiber Posts. J Dent Res. 2014 Jul;93(7 Suppl):52S-58S. doi: 10.1177/0022034514527970. Epub 2014 Mar 19.

10. Wandscher VF, Bergoli CD, Limberger IF, Ardenghi TM, Valandro LF. Preliminary Results of the Survival and Fracture Load of Roots Restored With Intracanal Posts:Weakened vs Nonweakened Roots. Oper Dent. 2014 Sep-0ct;39(5):541-55. doi: 10.2341/12-465. Epub 2014 Feb 6.

11. da Rosa RA, Bergoli CD, Kaizer OB, Valandro LF. Influence of cement thickness and mechanical cycling on the push-out bond strength between posts and root dentin. Gen Dent. 2011 Jul-Aug;59(4):e156-61.

12. Penelas AG, Piedade VM, Borges AC, Poskus LT, da Silva EM, Guimarães JG. Can cement film thickness influence bond strength and fracture resistance of fiber reinforced composite posts? Clin Oral Investig. 2016 May;20(4):849-55. doi: 10.1007/s00784-015-1568-3. Epub 2015 Aug 29.

13. Faria-e-Silva AL, Pedrosa-Filho Cde F, Menezes Mde S, Silveira DM, Martins LR. Effect of relining on fiber post retention to root canal. J Appl Oral Sci. 2009 Nov-Dec;17(6):600-4.

14. Grandini S, Goracci C, Monticelli F, Borracchini A, Ferrari M. SEM evaluation of the cement layer thickness after luting two different posts. J Adhes Dent. 2005 Autumn;7(3):235-40.

15. Higgins JPT, Green S. Cochrane Handbook for Systematic Reviews of Interventions Version 510. Cochrane Library; 2011. www.cochranehandbook.org

16. Moher D, Liberati A, Tetzlaff J, Altman DG; PRISMA Group. Preferred reporting items for systematic reviews and meta-analyses: the PRISMA Statement. PLoS Med. 2009 Jul 21;6(7):e1000097. doi: 10.1371/ journal.pmed.1000097. Epub 2009 Jul 21.

17. Moraes AP, Sarkis-Onofre R, Moraes RR, Cenci MS, Soares CJ, PereiraCenci T. Can Silanization Increase the Retention of Glass-fiber posts? A Systematic Review and Meta-analysis of In Vitro Studies. Oper Dent. 2015 Nov-Dec;40(6):567-80. doi: 10.2341/14-330-0. Epub 2015 Jul 7.

18. Valente LR, Sarkis-Onofre R, Gonçalves AP, Fernadez E, Loomans B, Moraes RR. Repair bond strength of dental composites: systematic review and meta-analysis. Int J Adhes Adhes. 2016;69:15-26.

19. Balkaya MC, Birdal IS. Effect or resin-based materials on fracture of endodontically treated thin-walled teeth. J Prosthet Dent. 2013 May;109(5):296-303. doi: 10.1016/S0022-3913(13)60304-2.

20. Silva GR, Santos-Filho PC, Simamoto-Júnior PC, Martins LR, Mota AS, Soares CJ.J. Effect of post type and restorative techniques on the strain and fracture resistance of flared incisor roots. Braz Dent J. 2011;22(3):230-7.

21. Barcellos RR, Correia DP, Farina AP, Mesquita MF, Ferraz CC, Cecchin $D$. Fracture resistance of endodontically treated teeth restored with intra-radicular post: The effects of post system and dentine thickness. J Biomech. 2013 0ct 18;46(15):2572-7. doi: 10.1016/j. jbiomech.2013.08.016. Epub 2013 Sep 7.

22. Ferro MC, Colucci V, Marques AG, Ribeiro RF, Silva-Sousa YT, Gomes EA. Fracture Strength of Weakened Anterior Teeth Associated to Different Reconstructive Techniques. Braz Dent J. 2016 SepOct;27(5):556-561. doi: 10.1590/0103-6440201602452.

23. Sarkis-Onofre R, Fergusson D, Cenci MS, Moher D, Pereira-Cenci T. Performance of Post-retained Single Crowns: A Systematic Review of Related Risk Factors. J Endod. 2017 Feb;43(2):175-183. doi: 10.1016/j. joen.2016.10.025.

24. Al-Omiri MK, Mahmoud AA, Rayyan MR, \& Abu-Hammad O. Fracture resistance of teeth restored with post-retained restorations: an overview. J Endod. 2010 Sep;36(9):1439-49. doi: 10.1016/j. joen.2010.06.005.

25. Santos AFV, Meira JBC, Tanaka CB, Xavier TA, Ballester RY, Lima RG, PFeifer CS, Versluis A. Can fiber post increase root stresses and reduce fracture? J Dent Res. 2010 Jun;89(6):587-91. doi: 10.1177/0022034510363382. Epub 2010 Mar 26.

26. Aggarwal V, Singla M, Miglani S, Kohli S. Comparative evaluation of fracture resistance of structurally compromised canals restored with 
different dowel methods. J Prosthodont. 2012 Jun;21(4):312-6. doi: 10.1111/j.1532-849X.2011.00827.x. Epub 2012 Feb 19.

27. Santos-Filho PC, Veríssimo C, Soares PV, Saltarelo RC, Soares CJ, Marcondes Martins LR. Influence of Ferrule, Post System, and Length on Biomechanical Behavior of Endodontically Treated Anterior Teeth. J Endod. 2014 Jan;40(1):119-23. doi: 10.1016/j.joen.2013.09.034. Epub 2013 0ct 27.
28. Scotti R, Ferrari M. Glass fiber post: Technical Considerations and Clinical applications. Artes Médicas; São Paulo: 2003. p7-23.

29. Shillingburg HT, et al. Preparations for extensively damaged teeth. In: Shillingburg HT, Sather DA, Wilson EL, Cain JR, Mitchell DL, Blanco L, et al. Fundamentals of fixed prosthodontics. Quintessence Publishing Company; Michigan: 1997. p181-209

\section{Lucas Pradebon Brondani}

(Corresponding address)

DDS, MSC, Department of Restorative Dentistry, University of Pelotas

Street Gonçalves Chaves, 457, 96015-560, Pelotas, Rio Grande do Sul, Brazil.

Phone: +55 53 3225-6741.

e-mail: lucaspradebon@gmail.com

Date submitted: 2018 0ct 10

Accept submission: 2018 Jan 28 